\title{
Uwagi po lekturze ksiażki autorstwa Andrzeja Korytki "Na których opiera się Rzeczpospolita". Senatorowie koronni za Władysława IV Wazy, Olsztyn 2015, 484 ss.
}

\author{
Abstract \\ Remarks after Reading Andrzej Korytko's Book 'Those the Polish Republic Leans \\ upon'. The Senators of the Crown during Wtadystaw JV Vasa's Reign, Olsztyn 2015, \\ 484 pp.
}

The review's author regards the reviewed book as an important attempt to study the senators of the Crown as a 'sejmujacy' class. The monograph presents a large quantity of details about the senators' participation in the parliament's works. However, Korytko focusses much more on the senators' political activities than on their legislative undertakings e. g. the author devotes much consideration to the problems of the senators' participation during the parliamentary and local assemblies' sessions. One would expect to pay much more attention to the role of the senators in the procedure of convening the General Sejm by deliberatoria and in the legislative and control functions of the Polish-Lithuanian parliament.

Keywords: Polish-Lithuanian Commonwealth, General Sejm, 'sejmujący' class, senators

Słowa kluczowe: Rzeczpospolita Obojga Narodów, sejm walny, stan sejmujący, senatorowie

Badania naukowe dotyczące dziejów polskiego parlamentaryzmu odnoszą się do kwestii regulacji prawnych i praktyki sejmowej. Im bliżej naszych czasów, tym większą mamy możliwość, na podstawie norm prawnych, analizować praktykę ich stosowania. Odnośnie do okresu staropolskiego sytuacja przedstawia się odmiennie; nie tylko musimy skonstatować fakt, że przepisów prawa stanowionego dotyczących zagadnień parlamentarnych mamy bardzo mało, trzeba się opierać na skrzętnie wyszperanych zwyczajach sejmowych, a nawet z zebranego materiału archiwalnego, głównie w postaci diariuszy, czyli sprawozdań sejmowych z obrad poszczególnych sejmów, wydobywać 
reguły sejmowania: funkcji sejmu, jego zadań i kompetencji, procedury legislacyjnej, rodzaju dorobku sejmowego.

Wielce obiecująca zapowiedź autora, że „niniejsze opracowanie jest próbą spojrzenia na senatorów koronnych jako na stan sejmujący" (s. 9), wzbudza z pewnością zainteresowanie historyka prawa, rodzi bowiem nadzieję na ujęcie instytucjonalne senatu w omawianym okresie. W tym celu należałoby zdefiniować pojęcie stanu sejmującego, choć wydawałoby się, że kwestia ta była już wiele razy omówiona w literaturze. W rzeczywistości jednak badacze posługują się określeniem „stan sejmujący” bez próby doktrynalnego wyjaśnienia jego znaczenia. Nie inaczej jest $\mathrm{i}$ w tym wypadku, bowiem autor nie poświęcił temu pojęciu żadnej refleksji.

Skoro przedmiotem opracowania jest instytucja (,stan sejmujący”), to historyk prawa oczekuje na przedstawienie roli i znaczenia senatorów na forum sejmowym; jest to bowiem główny cel autora, i to nie tylko w ujęciu głównie politycznym, ale także ustrojowo-prawnym. Jako stan sejmujący senat brał udział w obradach sejmu, a głównym zadaniem tego najważniejszego organu było jeszcze wówczas stanowienie prawa; a zatem partycypacja senatorów w akcji sejmowej, rozumianej jako szereg czynności zmierzających do zwołania, odbycia i sfinalizowania sejmu w postaci uchwał, winna znaleźć w publikacji swoje należne miejsce. Dlatego dziwić może brak uwzględnienia kwestii listów deliberatoryjnych, kierowanych do senatorów przez króla w sprawie miejsca, czasu oraz programu obrad planowanego sejmu, a także odpowiedzi na tę korespondencję ze strony członków senatu. Autor opracowania rozwodzi się nad udziałem senatorów w sejmikach przedsejmowych, w szczególności poświęcając dużo uwagi przykładowo uchwałom i instrukcjom sejmikowym w interesie senatorów, podziękowaniom dla nich lub przeciwko senatorom, natomiast pomija kwestie dla głównej tematyki szczególnie ważne, skoro senatorowie brali udział w procedurze zwołania sejmu.

Gdyby badacz zajął się zagadnieniem odpowiedzi senatorów na listy deliberatoryjne, z pewnością zetknąłby się z problematyką sejmów zwyczajnych i nadzwyczajnych, a tym samym miałby okazję ustosunkować się do przepisu artykułów henrykowskich nakazujących królowi zwoływanie sejmu co dwa lata, a za radą senatorów częściej, jeśli tego będzie wymagać dobro Rzeczypospolitej. Czy zatem władca miał obowiązek rozsyłać listy deliberatoryjne i oczekiwać na odpowiedzi ze strony senatorów w przypadku sejmów ordynaryjnych oraz ekstraordynaryjnych - nie dowiemy się, gdyż autor zupełnie pominął tę kwestię.

Omawiając inaugurację sejmu od odprawiania nabożeństwa, badacz zastrzega, że „nie wdaje się w tym miejscu w rozważania, czy nabożeństwo inaugurujące obrady sejmu było tylko ceremoniałem, czy regulaminową częścią obrad" (s. 109, przyp. 1). Autor nie pochylił się więc nad znaczeniem ceremoniału i tego, czy ów ceremoniał należał do czynności regulaminowych. W źródłach znane było i bardzo często używane określenie solemnitates (solennitates). Warto byłoby stwierdzić, czy nabożeństwo nie należało do tego rodzaju czynności sejmowych. Skoro jednak celem autora było omówienie funkcjonowania stanu sejmującego, a wraz z nim i podstawowych etapów prac sejmowych, powinien się do tej materii odnieść. W zakończeniu jedynie przykładowo nabożeństwo jest traktowane jako ceremoniał, który tworzy „trwałą wartość - kulturę polityczną” (s. 396). Brak oceny ceremonialnych, uroczystych punktów porządku sejmowania z prawnego, a nie tylko politycznego punktu widzenia. 
Za „otwarcie właściwych obrad” badacz uznaje witanie króla (s. 110). Na pytanie, czy przewidziany w artykułach henrykowskich sześciotygodniowy czas trwania sejmu należało liczyć od dnia odprawienia mszy świętej czy witania króla, nie znajdujemy odpowiedzi. Czy zatem senatorowie w istocie po nabożeństwie, kierując się do sali senatorskiej, jedynie oczekiwali na wybór marszałka poselskiego i powiadomienie ich o tym fakcie przez delegacje poselską; wszak pytanie, czy siedzieli tak bezczynnie czasem kilka dni, nie jest bezzasadne. Przykładowo za czasów poprzednika Władysława IV Zygmunta III Wazy - odbywały się narady senatu w sprawie uregulowania porządku i dyscypliny w trakcie obrad sejmowych. Należy wątpić, że ten punkt w ówczesnym regulaminie sejmowym został zarzucony za jego następcy.

W dalszej kolejności A. Korytko omawia niezmiernie istotną kwestię wotów senatorskich jako punktu procedury sejmowej. Nie została ona jednak ujęta w rozdziale czwartym, traktującym o sejmowej działalności senatorów. Czymże zatem owe wota były, jeśli właśnie nie sejmową działalnością senatorów, zwłaszcza że tak ten rodzaj aktywności członków izby wyższej nazywa sam autor we wstępie na s. 10. Zagadnieniem niezwykle istotnym jest to, jakie funkcje pełniły wota senatorskie, a w szczególności czy miały znaczenie dla procedury legislacyjnej. Jednak w podrozdziale 3.2. autor jedynie stwierdza, że były „nieodłącznym elementem procedury sejmowej”, poświęcając tę część głównie kwestii frekwencji, podejścia senatorów i posłów do roli wotów, sylwetkom oratorów i niekrasomówców. Na marginesie należy skonstatować, że niezwykle dużo miejsca w swoim opracowaniu autor przeznaczył na omówienie frekwencji (na sejmach: s. 54-109, w czasie wotów: s. 125-134, na sejmikach: s. 298-310, zakończenie: s. 393-397).

Badacz, skupiając się głównie na ich politycznym znaczeniu, zaledwie wspomina, że senatorowie w swoich wotach zawierali „projekty reformatorskie” (s. 140). Należałoby tej kwestii poświęcić znacznie więcej miejsca, w szczególności - przykładowo dokonać konfrontacji punktów propozycji sejmowej i poszczególnych wot w celu stwierdzenia, na ile odbiegały od owej propozycji, oraz wyciągnąc z tego stosowne wnioski. Czy wota miały zatem służyć poszerzeniu programu obrad, czy się w nim mieściły? Na to pytanie nie znajdujemy odpowiedzi. Ponadto warto się zastanowić, czy wotowanie senatorów miało istotne znaczenie z punktu widzenia wniosków ustawodawczych, ewentualnie szerszych propozycji ustawodawczych. Czy zatem senatorowie posiadali in gremio lub indywidualnie prawo inicjatywy ustawodawczej? Badacz wspomina przecież, że senatorowie „przychodzili z gotowymi projektami” do izby poselskiej, czy wreszcie wskazuje na projekt Krzysztofa Opalińskiego (s. 142-143). Na powyższe pytanie w książce brak odpowiedzi.

Interesująca byłaby również kwestia dalszego udziału senatu jako stanu sejmującego w procedurze legislacyjnej. W szczególności o kolejnych naradach senatorów autor nic nie wspomina (por. rozdz. 4), podobnie jak nie odnosi się do zagadnienia, czy senatorowie, mając w wyniku kontaktów z posłami wiedzę na temat projektów izby poselskiej, w toku obrad wyrażali jakieś stanowisko względem owych konceptów w formie konkluzji wstępnej czy czynili to dopiero w trakcie końcowej konkluzji wszystkich stanów sejmujących. Badacz, przywołując argumentację posłów przeciwko komisjom senatorsko-poselskim na sejmie w 1641 roku, iż nie należy senatu „przypuszczać ad concipiendas leges”, wyciągnął z tego wniosek, iż był to „atak na prawo wszystkich stanów 
do stanowienia ustaw" (s. 171). Nie można się zgodzić z taką interpretacją. Posłom chodziło bowiem o prawo do koncypowania konstytucji sejmowych, a więc ich projektowania $w$ formie konceptów, a nie stanowienia, czyli uchwalania ustaw, zwłaszcza że autor pisze, iż „nie ulega wątpliwości, że na projekt konstytucji musiały się zgodzić wszystkie stany sejmujące" (s. 227).

Istotną kwestią w dziejach polskiego parlamentaryzmu doby przedrozbiorowej było pojęcie weta, sprzeciwu, protestu (protestacji), kontradykcji. Badacz, przytaczając rozmaite poglądy w tej mierze, nie dokonał rozróżnienia ani nie zdefiniował tych terminów, a także nie pokusił się o własne rozstrzygnięcie problematyki skutków prawnych użycia tych instrumentów (s. 227, przyp. 377).

Autor nie poruszył również ważnego dla trybu legislacyjnego zagadnienia roli kanclerza; a przecież był to custos legum, mający za zadanie zbadać zgodność uchwał sejmowych z prawem pospolitym, co dla wcześniejszego okresu panowania odbywało się poprzez odmowę przyłożenia pieczęci.

Z tematyką funkcji prawodawczej sejmu walnego wiąże się ściśle kwestia charakterystyki jego dorobku ustawodawczego. $Z$ punktu widzenia roli senatorów interesujące jest zagadnienie ewentualnego ich udziału nie tylko w sesjach „pięczętarskich”, ale również w procedurze publikacji konstytucji, zwłaszcza jeśli z powodu zamknięcia ksiąg grodzkich trzeba było szukać innego sposobu ich upublicznienia. Czy sytuacje takie miały miejsce - autor nic o tym nie pisze. Poza tym, jak wiadomo, udział niektórych senatorów był widoczny w kwestii skryptów ad archiwum. $\mathrm{O}$ istnieniu takich aktów autor jedynie informuje (s. 201, przyp. 251), dokładniej nie rozważając tej tematyki.

Nie inaczej wygląda sprawa realizacji ewentualnej funkcji kontrolnej. Jeśli senatorowie w swoich wotach podejmowali krytykę króla, to na jakiej podstawie prawnej (być może wynikała ze złożonej przysięgi przy obejmowaniu urzędu) i czy mieli rację. Badacz wspomina o sytuacji, gdy na sejmie w 1639 roku kasztelan przemyski Felicjan Grochowski skrytykował Władysława IV za wyjazd do Baden bez zgody stanów. Autor pisze jedynie, że uczynił to „z pogwałceniem prawa”, nie dowiadujemy się jednak, o jakie przepisy chodziło, nie pokusił się o ich interpretację, aby wyjaśnić czytelnikom, czy senator miał rację, atakując króla. Gdyby się okazało, że senatorski stan sejmujący miał prawo kontroli władcy, po ustaleniu wykazu form tej kontroli na sejmie, to ustalenie wpisałoby się znakomicie w problematykę funkcji kontrolnych sejmu walnego, a zatem znacznie poszerzyłoby naszą wiedzę o staropolskim parlamentaryzmie. Jednak badacz nie zawarł w swojej monografii żadnych wniosków w tej mierze.

Ponadto należy dokonać oceny podejścia autora do ówczesnego systemu prawa; mianowicie przede wszystkim nie wiadomo, co A. Korytko uważa za „prawo”, skoro pisze: „wprawdzie prawo nie obowiązywało hetmana do składania sprawozdań, a jedynie obligował go do tego wypracowany zwyczaj" (s. 211). Prawo zwyczajowe, szczególnie będące w użyciu, miało taką samą wartość jak prawo stanowione, a może nawet większą, gdyż uważano je za „stare, dobre prawo”, utrwalone przez wieki. Kilkakrotnie też autor wyraża krytyczne stanowisko względem „literalnego interpretowania prawa”, za które uważa „uchwalone normy prawne”, którego jakoby senatorowie byli „zakładnikami" (s. 136, s. 233). Badacz dostrzega w takim ścisłym stosowaniu prawa wadę polskiego parlamentaryzmu. Po pierwsze, przepisów prawa stanowionego dotyczących funkcjonowania sejmu nie było wówczas wiele, większość działań sejmu opierała się 
na zwyczajach sejmowych (prawo zwyczajowe), po drugie, nie powinno to być dziwne, że posłowie, a także senatorowie chcieli być prawu posłuszni. W rzeczywistości, poza obligatoryjnymi punktami obrad, procedura była elastyczna, a powody napięć oraz rozrywania sejmów leżały zupełnie gdzie indziej; mianowicie były ściśle związane z konfliktami politycznymi inter maiestatem ac libertatem. Dodatkowo trzeba wytknąc autorowi, że artykuły henrykowskie nie były „dokumentem”, ale aktem prawnym (s. 247), oraz że zamiast słów: „przepis”, ,postanowienie”, notorycznie używa on w to miejsce określenia „zapis” („zapisy konstytucji”, s. 238); zapis to legat jako instytucja prawa spadkowego, znana od czasów prawa rzymskiego, nie zaś część aktu prawnego.

Reasumując, z pracy dowiadujemy się szczegółowo, ilu senatorów przybywało na sejmy i w którym momencie obrad, kto był oratorem, a kto miał problemy z wysławianiem się, którzy senatorowie i z jaką pompą wjeżdżali na obrady, w jakich ceremoniach brali udział, a nawet $\mathrm{w}$ jakich weselach czy pogrzebach oraz ucztach i biesiadach w czasie sejmu uczestniczyli, jednakże w kwestii zagadnień funkcji i zadań senatu jako stanu sejmującego opracowanie autora pozostawia spory niedosyt. 